\title{
An Overview of Fund Performance and Attributes: A Preliminary Relationship Analysis for Polish Mutual Funds
}

\author{
Dariusz Filip
}

\begin{abstract}
The aim of this study is to determine whether mutual fund attributes are related to investment performance. Organizational characteristics, such as size, age, family size and expense ratio, were collated with investment performance measured with the use of four different methods for a sample of 82 domestic equity funds operating in Poland in the period 2000-2015. The obtained results show that the asset size factor can translate into the generated return on investment. However, it must be indicated that this research is preliminary. It will enable the identification of the fund features which could be interpreted as determinants of performance in future studies employing more advanced research approaches.
\end{abstract}

Index Terms-Asset size, fund attributes, mutual funds, performance independence.

\section{INTRODUCTION}

Fund attributes could be described as organizational characteristics which determine the management profile of fund companies and which can help funds gain market advantage. The latest literature treats organizational aspects of the operation of mutual funds as potential determinants of performance.

The present study focuses on establishing whether fund attributes are related to investment results. This preliminary research enables the identification of the fund features which might be used as determinants of performance in future studies. It was possible to describe the image of an average equity fund on a developing market by compiling the characteristics of Polish mutual funds. Moreover, the structure of the data set was analyzed through descriptive statistics, including the determination of empirical distributions of individual variables. Later, it was possible to identify the relations between fund attributes and performance with the use of non-parametric tests. What was subject to a particular examination was the independence of the individual characteristics of funds and the investment results generated by such entities, the rank correlation of these variables, and the significance of the differences in the funds' returns classified into two independent subgroups related to specific fund attributes.

Manuscript received October 20, 2018; revised January 2, 2019. The presented work and results is part of project financially supported by the National Science Center (NCN), Poland, project no. 2014/15/D/HS4/01227 entitled: "Determinants of Mutual Fund Performance: Managerial characteristics and fund attributes".

D. Filip is with the Cardinal Stefan Wyszynski University, Warsaw, Wóycickiego 1/3, bl. 23, 01-938 Warsaw, Poland (e-mail: d.filip@uksw.edu.pl).
This research makes a contribution to the literature on Polish mutual funds and to the study of the fund performance-attributes relationship. Furthermore, it might be significant for asset management companies for practical reasons as the information about the above-mentioned relation, if any, could be exploited by fund managers for informational and advertising purposes

This study is composed of five parts. Part two contains a brief literature review and provides the grounds for formulating the hypotheses presented in the next section. Part three discusses the empirical design and data sources. Part four presents the obtained research results and precedes the summary of the major findings.

\section{LITERATURE REVIEW}

The literature dedicated to the operation of mutual funds is relatively abundant with studies aimed to evaluate the performance of this type of collective investment institutions. Analyses concerned with abnormal returns recorded by the discussed entities are mentioned among the most popular research streams. However, the researchers' interests have focused on various market anomalies for some time now. These include organizational factors, which could be treated as determinants of performance.

Among the studies which provide comprehensive presentations of fund attributes, interpreted as predictors of return on investment, the work by Golec [1] deserves a mention. Apart from managerial factors, he examined the level of administration fees, fund age, asset size, and organizational structure, which might influence performance to different degrees. Based on a sample of U.S. funds, he found that funds with lower fees and more diversified portfolios achieved better results.

Payne, Prather, and Bertin [2] added the turnover ratio and the minimal initial investment to the above set of attributes. The obtained results proved a relation between performance and some of the independent variables. For instance, fund size and age were not significant for the generated performance, whereas expense ratio and organizational structure had an adverse influence on rates of return.

One of the most commonly invoked studies is one by Chen, Hong, Huang, and Kubik [3]. Using a sample of U.S. equity funds, they carried out a cross-sectional analysis examining whether there was a relation between fund size and other characteristics, such as turnover ratio, fund age, expense ratio, front-end load, flow of assets, and fund return over the past 12 months. Based on the obtained results, it was noted that 
investment performance decreased as the assets held by the fund increased both after and before deducting fees and expenses. Moreover, small funds were usually managed by one manager, while large ones - by teams of managers, which translated into a more frequent inclusion of local companies in the portfolio.

Ferreira, Keswani, Miguel, and Ramos [4], in turn, analyzed performance determinants of open-end actively managed mutual funds from 27 countries. The examination covered an extensive list of fund characteristics, such as fund size and family size, fund age, fees and expenses, fund flows, past performance, management structure, and number of countries where units are sold. They found that mutual funds achieved performance below the benchmark. Additionally, the obtained results pointed to significant differences between the factors influencing fund performance in the U.S.A. and in other analyzed countries. The evidence for the diminishing economies of scale regarding American funds deviated from the results concerning the size of funds located outside the U.S.A. The mentioned authors noted also that an average American mutual fund was over five times larger than one located in a different country.

For the sake of comparison, Perold, and Salomon [5] were among the first researchers to show that in the case of a larger base of assets, funds are forced to manage the portfolio actively, which leads to growth in expenses due to a higher number of transactions. They also found that average-sized funds generated the best results, yet - as a general rule performance deteriorated as fund size increased. On the other hand, as a result of their assessment of U.S. equity funds, Droms and Walker [6], stated that the performance achieved by an equity fund was not significantly related to its size. Nevertheless, it was noticed that load funds outperformed no-load ones.

However, the studies arguing that the entities operating on the market strive for the optimal asset size to achieve relatively good results have been published in scientific periodicals for some time now. The hypothesis on the existence of an inverse relationship between the size of assets under management and fund performance was confirmed, among others, in the study by Switzer, and Huang [7]. Although the main area of the research regarded the features of managers themselves, they showed that the mutual funds where assets fell into the range of USD 1.43B-3.89B achieved the best results.

Other works, such as Bodson, Cavenaile, and Sougne [8], or Tang, Wang, and $\mathrm{Xu}$ [9], are consistent with the stream of research confirming the existence of the optimal size of assets. The former study noticed, based on the use of the linear and quadratic regression models, a concave quadratic relationship between fund performance and size for equity and bond funds. The latter one also discerned the existence of an inverted U-shaped relationship between fund size and performance as a result of an analysis of Chinese open-end equity funds. The parabolic shape of the examined relationship means that, at initial growth stages, funds achieve a cost advantage, i.e. research and marketing costs do not increase in a uniform manner with respect to fund size. However, a negative relation concerning the analyzed variables, which contradicts the economies of scale thesis, could occur when a fund exceeds the optimal size.

In general terms, the relevant literature on the impact of fund attributes on performance does not provide clear-cut results. There are also studies which review the independence of individual fund characteristics and the entities' returns on investment. For example, Fuss, Kaiser, and Strittmatter [10] examined the attributes of funds of hedge funds with fund size and age among the analyzed features. The researchers noticed a positive correlation between fund size and age by means of quantile regression. Moreover, the obtained results suggested that age and size had a negative impact on performance with a positive curvature at the top quantiles. Nevertheless, the size factor had a positive influence on performance with a negative curvature at the bottom quantile.

The works discussed above come mainly from developed markets. The issue of fund attributes is rarely taken up in the European literature and studies from CEE countries, including Poland, are restricted virtually to the analysis of mutual fund performance (e.g. [11] and [12]). To the best knowledge of the author, there are only two studies on the Polish mutual fund industry that concern certain fund characteristics in relation to performance. Białkowski, and Otten [13] were the first to refer to such fund features as: expense ratio, asset size and fund age. In the case of expense ratio and fund age, a negative, albeit an insignificant, effect on performance was noticed. As regards the fund size factor, it proved to be statistically significant and had a positive influence on investment results. Economies of scale in the context of fund size were studied also by Filip [14] who, having analyzed the size-performance relationship for three selected CEE countries, ascertained that the performance erosion effect did not exist in the Czech Republic, Hungary or Poland. This means that risk-adjusted returns slightly improved as assets under management increased.

The analyses performed in this study with respect to the discussed area endeavor to fill in the existing research gap. At the same time, the paper could constitute a contribution to the relevant literature by indicating the differences and similarities between the findings of the study and the outcome of the existing literature due to the unique context of the research on the local market.

\section{DESCRIPTION OF THE PROCEDURE AND DATA}

The literature review enabled the formulation of the research objective and a few hypotheses. The aim of this study is to determine whether fund attributes are related to investment performance. The research hypotheses under verification provide that:

H1: There is no correlation between fund performance and attributes.

H2: There are no significant differences in performance among individual fund subgroups distinguished by fund attributes.

H3: Fund characteristics and investment performance are independent.

The presented research hypotheses were verified by means of a set of three research methods, which are described below. Fund size, fund age, expense ratio, and family size were 
distinguished as part of the collation of fund attributes.

\section{A. Empirical Approaches}

As was mentioned earlier, this research is preliminary. The data set structure was analyzed through descriptive statistics, including the determination of empirical distributions of individual variables. The tools applied here were the well-known Kołmogorow-Smirnov test with Lilliefors significance correction and the Shapiro-Wilk test of normality Then, the employment of non-parametric tests enabled the identification of relations between fund attributes and performance. To this end, it was crucial to examine the independence of the individual fund characteristics and the entities' return on investment, the correlations between the variables, and the significance of the differences in the results in two separate subgroups connected with specific fund attributes. The independence of particular variables was determined based on pairwise comparisons. The indicators used for this purpose were the classical $c h i$-squared test and phi contingency coefficient. The mentioned correlation, in turn, was measured with Spearman's rank correlation coefficient, which is frequently applied when analyzing mutual fund performance [e.g. 15]. The examination of the differences in two independent groups was performed with the use of medians based on the Mann-Whitney $U$ test and the Wilcoxon signed-rank test.

\section{B. The Sample}

The time horizon for this research covered the period 2000-2015. The data set consisting of units of 82 registered domestic equity funds as well as of organizational characteristics in the form of size, age, expense ratio and family size, was derived from the reports by Analizy Online, a rating website. It needs to be indicated that there were only 10 entities with the investment policy taken into account in the research in place in the initial period of the analysis, yet their number increased year by year. This means that there was survivorship bias in the study sample. However, as the research conducted to date has shown, the power and volume of its effect are negligible [16]. Summary statistics of the applied fund attributes are presented in Table I.

TABLE I: DESCRIPTIVE STATISTICS FOR FUND ATTRIBUTES

\begin{tabular}{lrrrr}
\hline \hline & LN(Size) & LN(Age) & Expense & LN(Family) \\
\hline No. of Observations & 711 & 690 & 678 & 714 \\
Mean & 18.234 & 3.902 & 0.039 & 21.499 \\
Median & 18.415 & 4.078 & 0.040 & 21.510 \\
Mode & 10.692 & 2.565 & 0.147 & 20.283 \\
Minimum & 10.692 & 0.693 & 0.001 & 15.422 \\
Maximum & 22.412 & 5.481 & 0.147 & 24.080 \\
Range & 11.720 & 4.787 & 0.147 & 8.658 \\
Lower Quartile & 17.118 & 3.367 & 0.037 & 20.869 \\
Upper Quartile & 19.502 & 4.595 & 0.041 & 22.701 \\
Interquartile Range & 2.384 & 1.228 & 0.005 & 1.832 \\
Sample Variance & 3.446 & 0.932 & 0.000 & 1.956 \\
Standard Deviation & 1.856 & 0.965 & 0.015 & 1.399 \\
Coefficient of Variation & 0.102 & 0.247 & 0.372 & 0.065 \\
Kurtosis & 0.700 & 0.616 & 15.013 & 1.291 \\
Skewness & -0.536 & -0.900 & 1.960 & -0.786 \\
Kołmogorow-Smirnov & 0.051 & 0.088 & 0.230 & 0.078 \\
Shapiro-Wilk & 0.985 & 0.944 & 0.726 & 0.958 \\
\hline \hline
\end{tabular}

Source: Own study

As presented in Table I, the greatest variability was reported for size characteristics and the lowest - for expense ratio. Quite large ranges of fund size and family size could lead to the lack of relative concentration of scores in the center. Moreover, it should be noted that the raw data of size, age and family size were log-transformed into approximately normal data. Nevertheless, for all of the above-mentioned variables, the kurtosis was less than 3 and hence the distribution was a platykurtic with light tails. For the expense ratio, which was characterized by a relatively high value of peakedness, the distribution was leptokurtic with heavier tails. The values of the skewness coefficient, which showed the asymmetry of the probability distribution, indicated a positive or negative skew for all of the variables. The lack of normal distributions for the values of fund attributes were confirmed by three normality tests.

\section{The Measurement of Return}

The gathered data concern unit prices of mutual funds. These data allowed the calculation of the effects of asset management, which were measured by the most popular risk-adjusted returns. The first tool for evaluating the quality of asset management was the original Sharpe ratio [17], called the reward-to-variability measure. The pre-modification in the 1994 formula was applied:

$$
\text { Sharpe }_{i, t}=\frac{\overline{r_{i, t}}-r_{f, t}}{\sigma\left(r_{i, t}\right)}
$$

where: Sharpe $_{i, t}$ is the Sharpe ratio of return on fund $i$ in period $t ; r_{i, t}$ is the mean rate of return achieved over period $t$ by fund $i ; r_{f, t}$ stands for the mean risk-free return over the analogous period; $\sigma\left(r_{i, t}\right)$ is the standard deviation of the rate of return on fund $i$ in period $t$, and it represents unsystematic risk.

The mean rate of return and the standard deviation were calculated on the basis of monthly observations.

The second measure of return was similar to the previous one but it included systematic risk. The reward-to-volatility ratio, also known as the Treynor ratio [18], was computed as follows:

$$
\text { Treynor }_{i, t}=\frac{\overline{r_{i, t}}-r_{f, t}}{\beta\left(r_{i, t}\right)}
$$

where: Treynor $_{i, t}$ is the Treynor measure of return on fund $i$ in period $t ; \beta\left(r_{i, t}\right)$ stands for values of systematic risk of fund $i$ and estimated sensitivity of the fund return to the benchmark variations. Beta values were calculated on the basis of monthly observations.

The next measure of return was Jensen's alpha [19], calculated as an intercept of appropriately constructed one-factor regression models. The ground for estimating the mentioned parameters was the CAPM model from the following equation:

$$
\text { Jensen }_{i, t}=r_{i, t}-\left(r_{f, t}+\beta\left(r_{m, t}-r_{f, t}\right)\right)
$$

where: Jensen $_{i, t}$ is the measure of return on fund $i$ in period $t$; $r_{m, t}$ is the return on the local equity market benchmark in period $t$. In order to obtain yearly returns, the observations related to estimations of Jensen's alphas were made on a monthly basis.

The last ratio used was the Carhart measure [20]. In this 
case, the risk-adjusted return was calculated also as an intercept of the CAPM models, yet with four mimicking factors on the Polish capital market. The mentioned author expanded Fama and French's three-factor procedure [21] by the momentum effect, described by Jegadeesh and Titman [22], according to the following formula:

$$
\begin{aligned}
& \operatorname{Carhart}_{i, t}=r_{i, t}-\left(r_{f, t}+\beta\left(r_{m, t}-r_{f, t}\right)+\beta_{S M B}\left(S M B-r_{f, t}\right)\right. \\
& \left.+\beta_{H M L}\left(H M L-r_{f, t}\right)+\beta_{U M D}\left(U M D-r_{f, t}\right)\right)
\end{aligned}
$$

where: Carhart $_{i, t}$ is the measure of return on fund $i$ in period $t$; $r_{S M B}$ is the simple excess return on the $S M B$ portfolio in period $t$, which means a difference in return between the small stock portfolio and the big stock portfolio; $r_{H M L}$ is the simple excess return on the $H M L$ portfolio interpreted as the difference in return between the high book-to-market portfolio and the low book-to-market portfolio in period $t ; r_{U M D}$ is the simple excess return on the $U M D$ portfolio, which means the difference in returns between a portfolio of past one-year winners and a portfolio of past one-year losers in period $t ; \beta_{i, S M B}, \beta_{i, H M L}$ and $\beta_{i, U M D}$ are the measures of sensitivity of the fund return to changes in the $S M B, H M L$ and $U M D$ factor returns, respectively.

The study adopted the annualised return on the stock market portfolio which was the main local market index (WIG). Benchmark's data were gathered form the Warsaw Stock Exchange (GPW), while the values of factor-mimicking portfolios were obtained courtesy of Adam Zaremba, who reports this kind of data on the website: http://adamzaremba.pl/downloadable-data/ [23]. A proxy for the riskless rate was the weighted average yield on 13-week T-bills sold at auctions. The data of risk-free rates were obtained from the International Financial Statistics quarterly reports prepared by the International Monetary Fund.

\section{RESULTS}

As regards the presented research hypotheses, the demonstrated findings were divided into three areas by the research methods applied. The obtained empirical results referred to the four analyzed fund attributes based on which asset allocation effects were evaluated.

The first of the methods, employed to verify the hypothesis on the correlation of fund performance and attributes, was Spearman's rank correlation coefficient analysis. Table II presents the values of correlation coefficients (rho) between fund attributes and investment performance.

TABLE II: SPEARMAN'S RANK CORRELATION COEFFICIENTS

\begin{tabular}{llrrrr}
\hline \hline & & LN(Size) & LN(Age) & Expense & LN(Family) \\
\hline \multirow{4}{*}{ Sharpe } & Spearman's rho & 0.1860 & -0.0396 & 0.0193 & 0.0880 \\
& Sig. (2-tailed) & 0.0000 & 0.3193 & 0.6334 & 0.0264 \\
& N & 634 & 634 & 611 & 634 \\
\hline \multirow{4}{*}{ Treynor } & Spearman's rho & 0.2070 & -0.0461 & 0.0051 & 0.1050 \\
& Sig. (2-tailed) & 0.0000 & 0.2583 & 0.9025 & 0.0099 \\
& N & 603 & 603 & 581 & 603 \\
\hline \multirow{4}{*}{ Alfa } & Spearman's rho & 0.0665 & -0.0587 & 0.0792 & 0.0473 \\
& Sig. (2-tailed) & 0.0943 & 0.1400 & 0.0503 & 0.2345 \\
& N & 634 & 634 & 611 & 634 \\
\hline \multirow{5}{*}{ Carhart } & Spearman's rho & -0.0442 & -0.0840 & 0.0395 & 0.0246 \\
& Sig. (2-tailed) & 0.2673 & 0.0342 & 0.3303 & 0.5366 \\
& N & 632 & 632 & 609 & 632 \\
\hline \hline
\end{tabular}

Source: Own study.
Table II presents the results of the correlation analysis. Due to the fact that the discussed variables are not normally distributed, Spearman's approach was selected for measuring the strength and direction of the correlations between the analyzed features. All of the pairwise compared variables were characterized by poor correlations, which means that no arguments for rejecting $H 1$ were found. The absence of correlations between fund attributes and performance could be significant for a regression analysis, if any, where it is possible to determine the influence of attributes on the asset allocation effects achieved by funds.

As a consequence of applying another research procedure, resulting in a division of funds into two groups by the value of the analyzed characteristic, it was possible to use non-parametric tests, which enabled the identification of the significance of the differences in the achieved returns on investment. Table III contains the information about the values of $Z$-statistics for the Mann-Whitney test and the Wilcoxon rank-sum test.

TABLE III: DIFFERENCES IN MUTUAL FUNDS' RETURNS CLASSIFIED INTO TWO INDEPENDENT GROUPS

Panel A: Size factor

\begin{tabular}{lcccc}
\hline \hline & Mann-Whitney $U$ & Wilcoxon $W$ & $Z$ & $\begin{array}{c}\text { Asymp. Sign. } \\
\text { (2-tailed) }\end{array}$ \\
\hline Sharpe ratio & 40250 & 81866 & -4.0620 & 0.0000 \\
Treynor ratio & 35454 & 70434 & -4.2743 & 0.0000 \\
Jensen's alpha & 46007 & 87623 & -1.5437 & 0.1227 \\
Carhart measure & 46292 & 105632 & -1.4190 & 0.1559 \\
\hline \hline
\end{tabular}

Panel B: Age factor

\section{Panel B: Age factor}

\begin{tabular}{lrrrr}
\hline & $\begin{array}{c}\text { Mann- } \\
\text { Whitney } U\end{array}$ & Wilcoxon $W$ & $Z$ & $\begin{array}{c}\text { Asymp. Sign. } \\
\text { (2-tailed) }\end{array}$ \\
\hline Sharpe ratio & 48493 & 88114 & -0.3606 & 0.7184 \\
Treynor ratio & 44164 & 102817 & -0.0593 & 0.9527 \\
Jensen's alpha & 48042 & 109818 & -0.5583 & 0.5766 \\
Carhart measure & 47520 & 109296 & -0.7872 & 0.4312 \\
\hline \hline
\end{tabular}

\begin{tabular}{|c|c|c|c|c|}
\hline & $\begin{array}{c}\text { Mann- } \\
\text { Whitney } U\end{array}$ & Wilcoxon $W$ & $Z$ & $\begin{array}{c}\text { Asymp. Sign. } \\
\text { (2-tailed) }\end{array}$ \\
\hline Sharpe ratio & 49615 & 94765 & -0.0807 & 0.9357 \\
\hline Treynor ratio & 44294 & 82797 & -0.2733 & 0.7846 \\
\hline Jensen's alpha & 48363 & 103641 & -0.6269 & 0.5307 \\
\hline Carhart measure & 48660 & 103938 & -0.4974 & 0.6189 \\
\hline \multicolumn{5}{|c|}{ Panel D: Family factor } \\
\hline & $\begin{array}{c}\text { Mann- } \\
\text { Whitney } U\end{array}$ & $\begin{array}{c}\text { Wilcoxon } \\
W \\
\end{array}$ & $Z$ & $\begin{array}{c}\text { Asymp. Sign. } \\
\text { (2-tailed) }\end{array}$ \\
\hline Sharpe ratio & 45996 & 91749 & -1.6722 & 0.0945 \\
\hline Treynor ratio & 40153 & 80908 & -2.2945 & 0.0218 \\
\hline Jensen's alpha & 47843 & 93596 & -0.8666 & 0.3862 \\
\hline Carhart measure & 45931 & 91684 & -1.7005 & 0.0890 \\
\hline
\end{tabular}

Panel C: Expense factor

Source: Own study

It was possible to formulate hypothesis $H 2$ under certain assumptions. They included, among others, statistical independence of all observations for both groups. In order to examine the significance of the differences between the distributions for two independent subsamples, we used the Wilcoxon-Mann-Whitney test (WMW). It should be mentioned that the WMW statistic does not require the assumption of normal distributions. The applied criterion of classification was the median of the analyzed fund attributes.

As Table III shows, the null hypothesis that two groups of funds classified by attributes come from the same population 
(i.e. have the same median of rates of returns) can be rejected only is some cases. Small mutual funds achieve significantly lower returns measured by Sharpe ratio and Treynor ratio than large funds. When family size was the grouping variable, the funds belonging to the large family achieved higher risk-adjusted returns than funds from the small fund family. This was confirmed at the significance level of $5 \%$ (for Treynor ratio) and $10 \%$ (for Sharpe ratio and Carhart measure). For the remaining results, there are no grounds for rejecting the null hypothesis $(H 2)$ and hence the distributions of the two consecutive subsamples are similar.

The scope of the collected data provided also the information about the independence of the variables with the use of crosstabs. Table IV presents a compilation of the aggregated values referring to the number of funds by the used classification criteria describing the analyzed entities.

TABLE IV: TESTS OF INDEPENDENCE BETwEen Fund ATtRIButes AND PERFoRMANCE

Panel A: Crosstabs for Sharpe ratio

\begin{tabular}{|c|c|c|c|c|c|c|c|c|c|c|}
\hline \multirow[t]{2}{*}{ LN(Size) } & $\begin{array}{l}\text { Smaller funds with } \\
\text { bad performance }\end{array}$ & $\begin{array}{l}\text { Larger funds with } \\
\text { bad performance }\end{array}$ & $\begin{array}{l}\text { Smaller funds with } \\
\text { good performance }\end{array}$ & $\begin{array}{l}\text { Larger funds with } \\
\text { good performance }\end{array}$ & chi-square & $p$-value & $P h i$ & $p$-value & $Z$ & $p$-value \\
\hline & 167 & 148 & 121 & 196 & 14.039 & 0.000 & 0.149 & 0.000 & 3.963 & 0.000 \\
\hline \multirow[t]{2}{*}{ LN(Age) } & $\begin{array}{l}\text { Younger funds with } \\
\text { bad performance }\end{array}$ & $\begin{array}{l}\text { Older funds with } \\
\text { bad performance }\end{array}$ & $\begin{array}{l}\text { Younger funds with } \\
\text { good performance }\end{array}$ & $\begin{array}{l}\text { Older funds with } \\
\text { good performance }\end{array}$ & chi-square & $p$-value & $P h i$ & $p$-value & $Z$ & $p$-value \\
\hline & 137 & 178 & 144 & 173 & 0.239 & 0.625 & -0.019 & 0.625 & -0.490 & 0.625 \\
\hline \multirow[t]{2}{*}{$\begin{array}{l}\text { Expense } \\
\text { ratio }\end{array}$} & $\begin{array}{l}\text { Cheaper funds with } \\
\text { bad performance }\end{array}$ & $\begin{array}{c}\text { More expensive } \\
\text { funds with bad } \\
\text { performance }\end{array}$ & $\begin{array}{l}\text { Cheaper funds with } \\
\text { good performance }\end{array}$ & $\begin{array}{l}\text { More expensive } \\
\text { funds with bad } \\
\text { performance }\end{array}$ & chi-square & $p$-value & $P h i$ & $p$-value & $Z$ & $p$-value \\
\hline & 167 & 148 & 165 & 152 & 0.059 & 0.808 & 0.010 & 0.808 & 0.243 & 0.808 \\
\hline \multirow[t]{2}{*}{ LN(Family) } & $\begin{array}{l}\text { Smaller family } \\
\text { funds with bad } \\
\text { performance }\end{array}$ & $\begin{array}{l}\text { Larger family } \\
\text { funds with bad } \\
\text { performance }\end{array}$ & $\begin{array}{l}\text { Smaller family } \\
\text { funds with good } \\
\text { performance }\end{array}$ & $\begin{array}{l}\text { Larger family } \\
\text { funds with good } \\
\text { performance }\end{array}$ & chi-square & $p$-value & $P h i$ & $p$-value & $Z$ & $p$-value \\
\hline & 162 & 153 & 140 & 177 & 3.342 & 0.068 & 0.073 & 0.068 & 1.852 & 0.068 \\
\hline
\end{tabular}

Panel B: Crosstabs for Treynor ratio

\begin{tabular}{|c|c|c|c|c|c|c|c|c|c|c|}
\hline \multirow[t]{2}{*}{ LN(Size) } & $\begin{array}{c}\text { Smaller funds with } \\
\text { bad performance }\end{array}$ & $\begin{array}{l}\text { Larger funds with } \\
\text { bad performance }\end{array}$ & $\begin{array}{l}\text { Smaller funds with } \\
\text { good performance }\end{array}$ & $\begin{array}{l}\text { Larger funds with } \\
\text { good performance }\end{array}$ & chi-square & $p$-value & Phi & $p$-value & $Z$ & $p$-value \\
\hline & 158 & 142 & 130 & 202 & 11.597 & 0.001 & 0.135 & 0.001 & 3.567 & 0.001 \\
\hline \multirow[t]{2}{*}{ LN(Age) } & $\begin{array}{l}\text { Younger funds with } \\
\text { bad performance }\end{array}$ & $\begin{array}{l}\text { Older funds with } \\
\text { bad performance }\end{array}$ & $\begin{array}{l}\text { Younger funds with } \\
\text { good performance }\end{array}$ & $\begin{array}{l}\text { Older funds with } \\
\text { good performance }\end{array}$ & chi-square & $p$-value & Phi & $p$-value & $Z$ & $p$-value \\
\hline & 127 & 173 & 154 & 178 & 1.048 & 0.306 & -0.041 & 0.306 & -1.028 & 0.306 \\
\hline \multirow[t]{2}{*}{$\begin{array}{l}\text { Expense } \\
\text { ratio }\end{array}$} & $\begin{array}{l}\text { Cheaper funds with } \\
\text { bad performance }\end{array}$ & $\begin{array}{l}\text { More expensive } \\
\text { funds with bad } \\
\text { performance }\end{array}$ & $\begin{array}{l}\text { Cheaper funds with } \\
\text { good performance }\end{array}$ & $\begin{array}{c}\text { More expensive } \\
\text { funds with bad } \\
\text { performance }\end{array}$ & chi-square & $p$-value & Phi & $p$-value & $Z$ & $p$-value \\
\hline & 161 & 139 & 171 & 161 & 0.295 & 0.587 & 0.022 & 0.587 & 0.544 & 0.587 \\
\hline \multirow[t]{2}{*}{ LN(Family) } & $\begin{array}{l}\text { Smaller family } \\
\text { funds with bad } \\
\text { performance }\end{array}$ & $\begin{array}{l}\text { Larger family } \\
\text { funds with bad } \\
\text { performance }\end{array}$ & $\begin{array}{l}\text { Smaller family } \\
\text { funds with good } \\
\text { performance }\end{array}$ & $\begin{array}{l}\text { Larger family } \\
\text { funds with good } \\
\text { performance }\end{array}$ & chi-square & $p$-value & Phi & $p$-value & $Z$ & $p$-value \\
\hline & 156 & 144 & 146 & 186 & 4.067 & 0.044 & 0.080 & 0.044 & 2.049 & 0.044 \\
\hline
\end{tabular}

Panel C: Crosstabs for Jensen's alpha

\begin{tabular}{|c|c|c|c|c|c|c|c|c|c|c|}
\hline \multirow[t]{2}{*}{ LN(Size) } & $\begin{array}{c}\text { Smaller funds with } \\
\text { bad performance }\end{array}$ & $\begin{array}{l}\text { Larger funds with } \\
\text { bad performance }\end{array}$ & $\begin{array}{l}\text { Smaller funds with } \\
\text { good performance }\end{array}$ & $\begin{array}{l}\text { Larger funds with } \\
\text { good performance }\end{array}$ & chi-square & $p$-value & Phi & $p$-value & $Z$ & $p$-value \\
\hline & 152 & 163 & 136 & 181 & 1.824 & 0.177 & 0.054 & 0.177 & 1.361 & 0.177 \\
\hline \multirow[t]{2}{*}{ LN(Age) } & $\begin{array}{l}\text { Younger funds with } \\
\text { bad performance }\end{array}$ & $\begin{array}{l}\text { Older funds with } \\
\text { bad performance }\end{array}$ & $\begin{array}{l}\text { Younger funds with } \\
\text { good performance }\end{array}$ & $\begin{array}{l}\text { Older funds with } \\
\text { good performance }\end{array}$ & chi-square & $p$-value & Phi & $p$-value & $Z$ & $p$-value \\
\hline & 134 & 181 & 147 & 170 & 0.940 & 0.332 & -0.039 & 0.332 & -0.973 & 0.332 \\
\hline \multirow[t]{2}{*}{$\begin{array}{l}\text { Expense } \\
\text { ratio }\end{array}$} & $\begin{array}{l}\text { Cheaper funds with } \\
\text { bad performance }\end{array}$ & $\begin{array}{l}\text { More expensive } \\
\text { funds with bad } \\
\text { performance }\end{array}$ & $\begin{array}{l}\text { Cheaper funds with } \\
\text { good performance }\end{array}$ & $\begin{array}{l}\text { More expensive } \\
\text { funds with bad } \\
\text { performance }\end{array}$ & chi-square & $p$-value & Phi & $p$-value & $Z$ & $p$-value \\
\hline & 167 & 148 & 165 & 152 & 0.059 & 0.808 & 0.010 & 0.808 & 0.243 & 0.808 \\
\hline \multirow[t]{2}{*}{ LN(Family) } & $\begin{array}{c}\text { Smaller family } \\
\text { funds with bad } \\
\text { performance }\end{array}$ & $\begin{array}{l}\text { Larger family } \\
\text { funds with bad } \\
\text { performance } \\
\end{array}$ & $\begin{array}{c}\text { Smaller family } \\
\text { funds with good } \\
\text { performance } \\
\end{array}$ & $\begin{array}{l}\text { Larger family } \\
\text { funds with good } \\
\text { performance } \\
\end{array}$ & chi-square & $p$-value & Phi & $p$-value & $Z$ & $p$-value \\
\hline & 152 & 163 & 150 & 167 & 0.055 & 0.814 & 0.009 & 0.814 & 0.235 & 0.814 \\
\hline
\end{tabular}

Panel D: Crosstabs for Carhart measure

\begin{tabular}{|c|c|c|c|c|c|c|c|c|c|c|}
\hline \multirow[t]{2}{*}{ LN(Size) } & $\begin{array}{c}\text { Smaller funds with } \\
\text { bad performance }\end{array}$ & $\begin{array}{l}\text { Larger funds with } \\
\text { bad performance }\end{array}$ & $\begin{array}{l}\text { Smaller funds with } \\
\text { good performance }\end{array}$ & $\begin{array}{l}\text { Larger funds with } \\
\text { good performance }\end{array}$ & chi-square & $p$-value & Phi & $p$-value & $Z$ & $p$-value \\
\hline & 139 & 177 & 149 & 167 & 0.638 & 0.424 & -0.032 & 0.424 & -0.801 & 0.424 \\
\hline \multirow[t]{2}{*}{ LN(Age) } & $\begin{array}{l}\text { Younger funds with } \\
\text { bad performance }\end{array}$ & $\begin{array}{l}\text { Older funds with } \\
\text { bad performance }\end{array}$ & $\begin{array}{l}\text { Younger funds with } \\
\text { good performance }\end{array}$ & $\begin{array}{l}\text { Older funds with } \\
\text { good performance }\end{array}$ & chi-square & $p$-value & Phi & $p$-value & $Z$ & $p$-value \\
\hline & 139 & 177 & 142 & 174 & 0.058 & 0.810 & -0.010 & 0.810 & -0.240 & 0.810 \\
\hline \multirow[t]{2}{*}{$\begin{array}{l}\text { Expense } \\
\text { ratio }\end{array}$} & $\begin{array}{l}\text { Cheaper funds with } \\
\text { bad performance }\end{array}$ & $\begin{array}{l}\text { More expensive } \\
\text { funds with bad } \\
\text { performance }\end{array}$ & $\begin{array}{l}\text { Cheaper funds with } \\
\text { good performance }\end{array}$ & $\begin{array}{l}\text { More expensive } \\
\text { funds with bad } \\
\text { performance }\end{array}$ & chi-square & $p$-value & Phi & $p$-value & $Z$ & $p$-value \\
\hline & 164 & 152 & 168 & 148 & 0.102 & 0.750 & -0.013 & 0.750 & -0.319 & 0.750 \\
\hline \multirow[t]{2}{*}{ LN(Family) } & $\begin{array}{l}\text { Smaller family } \\
\text { funds with bad } \\
\text { performance }\end{array}$ & $\begin{array}{l}\text { Larger family } \\
\text { funds with bad } \\
\text { performance }\end{array}$ & $\begin{array}{l}\text { Smaller family } \\
\text { funds with good } \\
\text { performance }\end{array}$ & $\begin{array}{l}\text { Larger family } \\
\text { funds with good } \\
\text { performance }\end{array}$ & chi-square & $p$-value & Phi & $p$-value & $Z$ & $p$-value \\
\hline & 164 & 152 & 138 & 178 & 4.287 & 0.038 & 0.082 & 0.038 & 2.106 & 0.038 \\
\hline
\end{tabular}


A cross tabulation is applied to aggregate and display the distribution of variables together by tabulating their scores one against the other in 2-dimensional grids. Like before, the used classification criterion was the median of the included variables, i.e. fund attributes and performance. Table IV shows the number of observations classified into four groups of funds. Moreover, the results of the non-parametric test of association are presented.

The frequencies of the funds classified as entities with bad performance and good performance, measured by means of Sharpe ratio and Treynor ratio, when size was the criterion of classification, permitted the identification of two groups with the highest number of observations. There were large funds with good performance and, to an extent, small funds with bad performance. The indirect identification was confirmed by two tests for independence: Pearson's $c h i$-square statistic and phi contingency coefficient. Both of them indicated a relationship between two categorical variables.

Similar findings were noticed for fund family size LN(Family). The funds belonging to a small fund family with bad performance and the funds from a large family with good performance were the most common ones. The measurement of association, carried out by means of tests for independence, also provided arguments for the alternative hypothesis on the dependence between size attributes and performance, measured by Sharpe ratio and Treynor ratio.

The results of crosstabs obtained for Jensen's alpha and Carhart measure did not indicate any statistically significant evidence to allow the rejection of the null hypothesis on the independence between row and column variables. For all analysed fund attributes, the frequency of observations was quite similar. In this case, there was no group of funds that would significantly predominate over others. This was confirmed by means of the values of contingency coefficients, which were relatively low. Overall, there was no relationship between fund attributes and measures of managers' selection ability reflected in performance.

\section{CONCLUSIONS}

As was mentioned before, fund attributes could be described as organizational characteristics which determine the management profile of fund companies. In general, organizational patterns might help funds gain market advantage. The latest literature treats fund attributes as a set of potential determinants of performance.

The aim of this paper was to determine whether fund attributes were associated with performance. For a sample of 82 domestic equity funds operating in Poland in the period 2000-2015, organizational characteristics, such as size, age, expense ratio and family size, were compared to returns on investment measured with Sharpe ratio and Treynor ratio, Jensen's alpha, and Carhart measure. Apart from the analysis of the data set structure, an attempt was made to identify the relations between fund attributes and performance. The independence of the individual fund features and the returns on investment generated by these entities, the correlations between the variables, and the significance of the differences in the results in two subgroups associated with particular fund attributes were analyzed by means of the applied tools.

The obtained results permit the identification of the characteristics of Polish equity funds and point to the lack of normal distribution of the variables. Moreover, no significant correlation between fund attributes and their returns on investment was found. It was noticed, however, that the asset size and fund family size factors could translate into the achieved investment results. This could be observed when analyzing the significance of the differences in the results of two subgroups related to specific fund attributes and while testing the independence of fund attributes and effects of asset allocation.

As was indicated earlier, this research is preliminary. It will enable the identification of the fund features which could be interpreted as determinants of performance in future studies applying more advanced research approaches. Nevertheless, the paper makes several contributions to the literature. The studies on the fund performance-attributes relationship, in particular determinants of mutual fund performance, are virtually non-existent in the Polish financial literature. Thus, the study begins to fill in the gap present in the Polish and Central and Eastern European research. Furthermore, the relationship seems significant for asset management companies since they might use it for advertising purposes.

\section{REFERENCES}

[1] J. H. Golec, "The effects of mutual fund managers' characteristics on their portfolio performance, risk and fees," Financial Services Review, vol. 5, no. 2, pp. 133-147, 1996.

[2] T. H. Payne, L. Prather, and W. Bertin, "Value creation and determinants of equity fund performance," Journal of Business Research, vol. 45, no. 1, pp. 69-74, 1999.

[3] J. Chen, H. Hong, M. Huang, and J. D. Kubik, "Does fund size erode performance? The role of liquidity and organization," The American Economic Review, vol. 94, no. 5, pp. 1276-1302, 2004.

[4] A. M. Ferreira, A. Keswani, A. F. Miguel, and S. B. Ramos, "The determinants of mutual fund performance. A cross-country study," Review of Finance, vol. 17, no. 2, pp. 483-525, 2013.

[5] A. Perold and R. Salomon, "The right amount of assets under management," Financial Analysts Journal, vol. 47, no. 3, pp. 31-39, 1991.

[6] W. G. Droms and D. A. Walker, "Mutual fund investment performance," The Quarterly Review of Economics and Finance, vol. 36, no. 3, pp. 347-363, 1996.

[7] L. N. Switzer and Y. Huang, "How does human capital affect the performance of small and mid-cap mutual funds?" Journal of Intellectual Capital, vol. 8, no. 4, pp. 666-681, 2007.

[8] L. Bodson, L. Cavenaile, and D. Sougne, "Does size affect mutual fund performance? A general approach," Journal of Asset Management, vol. 12, no. 3, pp. 163-171, 2011.

[9] K. Tang, W. Wang, and R. Xu, "Size and performance of Chinese mutual funds: The role of economy of scale and liquidity," Pacific-Basin Finance Journal, vol. 20, pp. 228-246, 2012.

[10] R. Fuss, D. G. Kaiser, and A. Strittmatter, "The Performance of Funds of Hedge Funds: Do Experience and Size Matter?" Journal of Alternative Investments, vol. 12, no. 2, pp. 41-53, 2009.

[11] P. Rzezniczak and L. A. P. Swinkels, "Performance evaluation of Polish mutual fund managers," International Journal of Emerging Markets, vol. 4, no. 1, pp. 26-42, 2009.

[12] G. Ünal and Ö. F. Tan, "Selectivity and market timing ability of polish fund managers analysis of selected equity funds," Procedia - Social and Behavioral Sciences, vol. 213, no. 1, pp. 411-416, 2015.

[13] J. Białkowski and R. Otten, "Emerging market mutual fund performance: Evidence for Poland," The North American Journal of Economics and Finance, vol. 22, no. 2, pp. 118-130, 2011.

[14] D. Filip, "Mutual funds: Does the performance erosion effect exist? Evidence from the Czech Republic, Hungary and Poland," Finance a úverr-Czech Journal of Economics and Finance, vol. 67, no. 6, pp. 512-538, 2017. 
[15] J. Huij and J. Derwall, "'Hot Hands' in bond funds," Journal of Banking \& Finance, vol. 32, no. 4, pp. 559-572, 2008.

[16] K. Perez, "Analyzing short-term persistence in Polish mutual funds performance," Advances in Global Management Development, vol. 20, pp. $157-164,2011$

[17] W. F. Sharpe, "Mutual funds performance," Journal of Business, vol. 39, no. 1, pp. 119-138, 1966.

[18] J. L. Treynor, "How to rate management of investment funds," Harvard Business Review, vol. 43, no. 1, pp. 63-75, 1965.

[19] M. Jensen, "The performance of mutual funds in the period 1945-1964," Journal of Finance, vol. 23, no. 1, pp. 389-416, 1968.

[20] M. M. Carhart, "On persistence in mutual fund performance," Journal of Finance, vol. 52, no. 1, pp. 57-82, 1997.

[21] E. F. Fama, K. R. French, "Common risk factors in the returns on stocks and bonds," Journal of Financial Economics, vol. 33, no. 1, pp. 3-56, 1993.

[22] N. Jegadeesh, S. Titman, "Returns to buying winners and selling losers: Implications for stock market efficiency," Journal of Finance, vol. 48, no. 1, pp. 65-91, 1993.
[23] A. Zaremba, P. Konieczka, "Size, value, and momentum in Polish equity returns: Local or international factors?" International Journal of Management and Economics, vol. 53, no. 3, pp. 26-47, 2017.

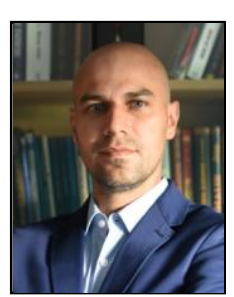

Dariusz Filip is an assistant professor of finance at the Cardinal Stefan Wyszynski University in Warsaw. He obtained his $\mathrm{Ph} . \mathrm{D}$. degree in economics at the Kozminski University in Warsaw. He has published in Finance a úvěr-Czech Journal of Economics and Finance, Baltic Journal of Economics, Prague Economic Papers, Journal of Economics and Management and Financial Assets and Investing. His research fields include the development of financial markets and financial institutions in CEE countries, effectiveness of mutual funds and determinants of their performance. 